\title{
Correlation BetweenStress Level And Juvenile Delinquency Level in Students of Sekolah Menengah Kejuruan 1 Kuripan, West Lombok
}

\author{
Dara Asyfiya Iyoega ${ }^{1}$, Herpan Syafii Harahap², Didit Yudhanto ${ }^{3}$, Pujiarohman ${ }^{4}$ \\ ${ }^{1}$ Medical Student, Faculty of Medicine, Universitas Mataram, Universitas Mataram. J1. \\ Pendidikan 37 Mataram, West Nusa Tenggara. Postal Code 83125. \\ 2Department of Neurology, Faculty of Medicine, Universitas Mataram \\ 3Department of Ear Nose Throat-Head and Neck Surgery, Faculty of Medicine, \\ Universitas Mataram. \\ ${ }^{4}$ Department of Psychology, Faculty of Medicine, Universitas Mataram.
}

Email: iyoega.daraasyfiya@gmail.com

Receive $:$ Jan $8^{\text {th }}$ 2020. Revised : Apr $4^{\text {th }}$ 2020. Published: June $27^{\text {th }} 2020$

DOI: https://doi.org/10.22219/sm.Vol16.SMUMM1.10851

\begin{abstract}
Juvenile delinquency is a kind of behavior that deviates from the norms prevailing in society. One factor that can affect the level of juvenile delinquency is stress. This study aimed to investigated thecorrelation between stress level and juvenile delinquency level in students of Sekolah Menegah Kejuruan (SMK) 1 Kuripan, West Lombok. This was cross-sectional involving 51 students of second and third-grade at Sekolah Menengah Kejuruan (SMK) 1 Kuripan, West Lombok. The data collected in this study were age, gender, stress level, and juvenile delinquency level. Stress level was measured using DASS-42 instrument, while juvenile delinquency levelwas measured using ASRDS instrument. The correlation between stress leveland juvenile delinquency level was analyzed using Gamma correlation test and the correlation was significant if $\mathrm{p}<0.05$. Most of the subjects showed mild stress levels $(62 \%)$ and normal delinquency levels $(78 \%)$. There was no significant correlation between stress levels and juvenile delinquency levels $(p=0.076)$. In conclusion, stress level instudents of SMK 1 Kuripandid not correlated to juvenile delinquency level.
\end{abstract}

Keywords: Stress level, juvenile delinquency level, DASS-42 instrument, ASRDS instrument.

Copyright (C) 2020, First Author et al This is an open access article under the CC-BY-SA license

\section{INTRODUCTION}

Adolescence is the period of transition between childhood and adulthood where delinquent behavior tends to occur. In 2008, the number of crime cases in Indonesia was about 346,000 cases, 4.3\% higher compared to those in 2007. According to The Indonesian National Police Report, 3,280 adolescents committed to crimes and 2,797 of them were male (KEMENPORA, 2009).

Previous studies had shown that the cause of juvenile delinquency were multifactorial and vary in different population studies. A study conducted by Riskinayasari (2015) showed that poor self-esteem caused juvenile delinquency. Poor communication between parents and their children 
was also a predisposing factor for the occurrence of poor self-esteem as well as juvenile delinquency (Pratiwi, 2016).

Juvenile delinquency can also be caused by external factors, such as the influence of family and school environmentsand peer groups. Family and school environment facilitates adolescents to control their behavior and respect others. Adolescent who raisedin supportive, affectionate, and accepting home are less likely to become delinquent.Based onsocial learning theory, peer groups may affect behavior of these members. A study conducted by Paternoster et.al (2013) showed that $38 \%$ of adolescent hadpeer group-related delinquent behavior. However, negative effect of peer group behavior may trigger stress that lead to delinquent behavior in adolescents (Masood \& Ali, 2018).

Stress in adolescents can be caused by internal and external stressors. Internal stressors can arise from an individual perception caused by internal conflict, and fears of inadequacy and nonspecific fears. External stressors identified are environmental stressor that consists of family, school, and general public environments. There are many aspects of life that can causedexternal stressors, such as excessive responsibilities and lack of opportunity for advancement. All of these stressors may inducebiological and psychological responses of the body that lead to behavioral changes with subsequent the generation of either positive or negative behavior. Stress-induced negative behavior will lead to juvenile delinquency (Larue \& Herman 2008; Papathanasiou, et.al., 2015).

This was the first study aimed to investigatedthe correlation between stress level and juvenile delinquency level in students of Sekolah Menengah Kejuruan (SMK) 1 Kuripan, West Lombok. Sekolah Menengah Kejuruan is a vocational high school which has same grade but different program with senior high school.

\section{METHODS}

This was cross-sectional study involving students of SMK 1 Kuripan, West Lombok that fulfilled the inclusion but not exclusion criteria. The inclusion criteria were students in the $2^{\text {nd }}$ and $3^{\text {rd }}$ grade at SMK 1 Kuripan, aged 15-19 years old, has signed informed consent and willing to fill the questionnaire voluntarily. The exclusion criteria were students who have been diagnosed with psychiatric disorder (schizophreniaand affective bipolar disorder). This study was conducted in the period of June-December 2019. This study had been approved by Komisi Etik Penelitian Kesehatan of Universitas Mataram with number325/UN18.F7/ETIK/2019.

The data collected in this study were age, gender, grade of students, stress level, and juvenile delinquency level. The age was divided into 4 groups, i.e 15, 16,17, and 18 years old. Grade of students in SMK was divided into 2 categories, $2^{\text {nd }}$ and $3^{\text {rd }}$ grades. Stress levelwasassessed using a Depression, Anxiety and stress Scale (DASS-42) instruments. The total score of DASS-42 
instruments for stress category $(0-42)$ was graded into 5 levels representing the level of stress, i.e normal (score of 0-14), mild (15-18), moderate (19-25), severe (26-33), and extremely severe ( $\geq 34)$ respectively. Juvenile delinquency levelwasassessed usingThe Adoption Delinquency Self Report Scale (ASRDS) instrument. The total score of ASRDS instrument (0-105) was then graded into 5 levels representing the juvenile delinquency level of the subjects, i.e normal (score of 35-49), mild (50-64), moderate (65-79), severe (80-94), and extremely severe ( $\geq 95)$, respectively.

The characteristics data collected in this study were presented in frequency table. The correlation between stress level and juvenile delinquency level was analyzed using Gamma correlation test, and so the correlation between grade of students and juvenile delinquency level. The correlation between gender and juvenile delinquency level was analyzed using Coefficient contingency test. The correlation between age of students and juvenile delinquency level was analyzed using Gamma correlation test. The correlation test were significant if $\mathrm{p}<0.05$.

\section{RESULTS AND DISCUSSION}

The eligible subjects participated in this study were 51 students. Most of the subjects were in $2^{\text {ndgrade }}(72.5 \%)$ and aged 16 to 17 years. The proportion of female subjects were slightly higher compared to male $(52.9 \%$ vs $47.1 \%)$. Most of the subjects showed mild stress $(62.7 \%)$ and normal delinquency level (78.4\%) (table 1).

Table 1. Characteristics of the subjects

\begin{tabular}{lcc}
\hline Category & Sub-category & Total, $\mathrm{n}(\%)$ \\
\hline Age in years & 15 & $2(3.9)$ \\
& 16 & $23(45.1)$ \\
& 17 & $22(43.1)$ \\
Gender & Male & $4(7.8)$ \\
& Female & $24(47.1)$ \\
Grade of students & $2^{\text {nd }}$ & $27(52.9)$ \\
Stress levels & $3^{\text {rd }}$ & $37(72.5)$ \\
& Normal & $14(27.5)$ \\
& Mild & $0(0)$ \\
& Moderate & $32(62.7)$ \\
& Severe & $18(35.3)$
\end{tabular}


Extremely severe

Juvenile delinquency levels

$\begin{array}{lc}\text { Normal } & 40(78.4) \\ \text { Mild } & 9(17.6)\end{array}$

Moderate

Severe

Extremely severe
$0(0)$

$0(0)$

The present study showed that the proportion of subjects with mild stress level $(62.7 \%)$ was higher compared to those with moderate stress level (35.3\%). The previousstudy on stress levels of students in the third grade at senior high school conducted by Wulandari (2009) showed that $36.26 \%$ had mild category, while $63.74 \%$ had moderate category. The present study also showed that $1.9 \%$ of subjects had severe stress level, a finding that did not exist in the previous study. The different results between the present study and previous study conducted by Wulandari (2009) might be due to different either internal and external stressors of population studied. The different stimuliwill give rise to different perception as well as varying stress levels (Larue \& Herman, 2008).

Some conditions thatmay affect delinquent behavior are age, educational stage, and gender (Sumara, et.al, 2017; Hyland, 2018). In the present study, the subjects were the students of second and third grades in vocational high school aged 15 - 18 years old. The differences in the characteristics of subjects might cause the level of delinquency found to vary. Most subjects had normal juvenile delinquency level(78.4\%), while those with mild and moderate level were $(17.6 \%$ and $3.9 \%$ ) respectively.

The present study showed no significant correlation between stress level and juvenile delinquency level( $(\mathrm{p}>0.05)$ (table 2). Previous study conducted by Luluk et al (2015) showed different results, there was significant correlation between stress level and juvenile delinquency level. This different result is attributed to the difference in characteristics of the subjects, in terms of age, educational stage, environment, or the type of juvenile delinquency itself. Subjects in the previous study were students of $3^{\text {rd }}$ grade at Sekolah Menengah Pertama (SMP) 13 Yogyakarta, while subjects in the present study were students in the second and third grade at SMK 1 Kuripan, West Lombok. The type of juvenile delinquency is vary, ranged from norm prevailing to unlawful act. The stress level is only representing one of identifiablepredisposing factors that can affect the level of delinquency. Other predisposing factors for juvenile delinquency were also identified in this study, namely gender, age and grade of students. The present study showed that gender and grade but not age of subjects were significantly correlated to juvenile delinquency level (table 2). 
Table 2. Correlation between stress levels, gender, age, and education with juvenile delinquency

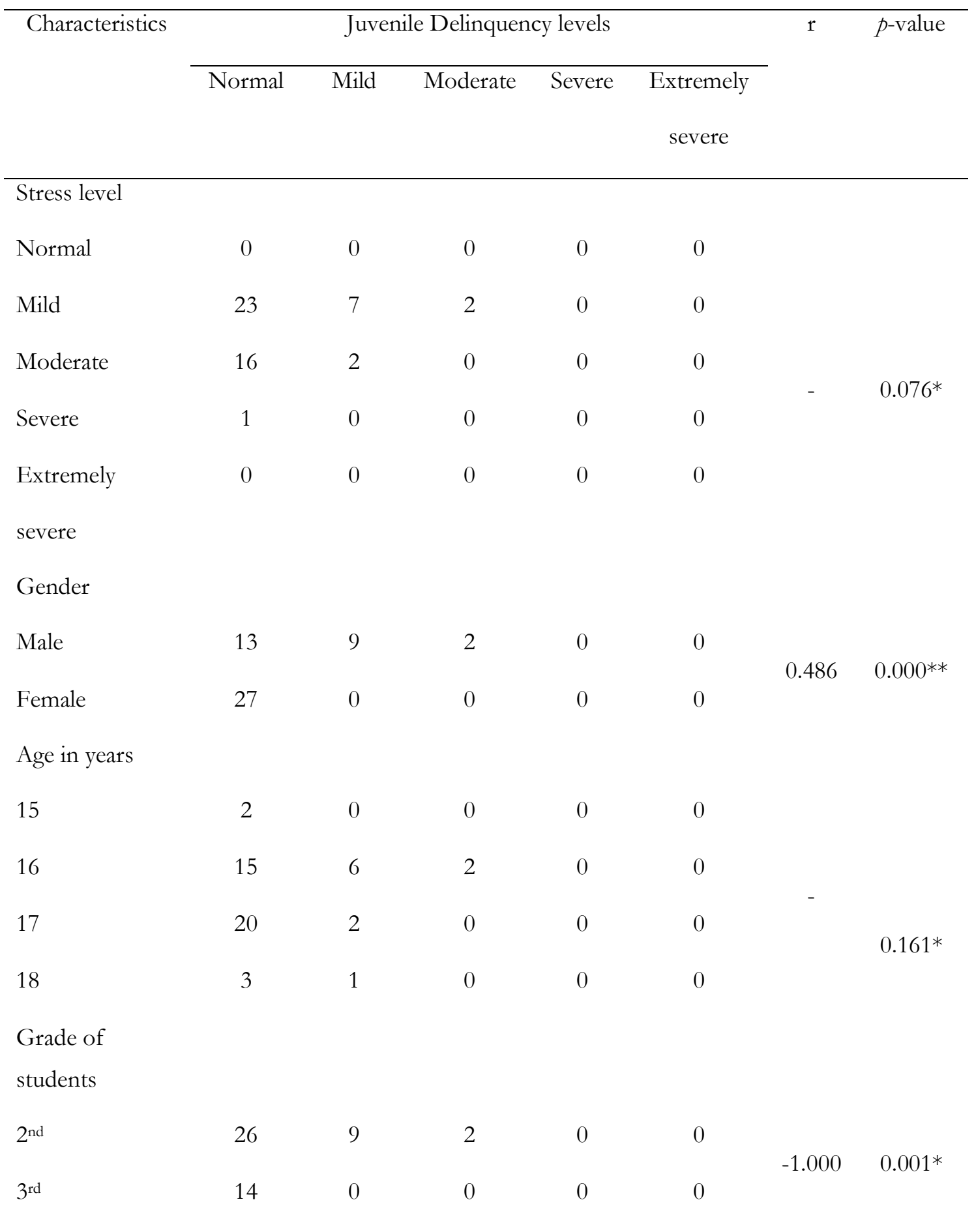

*Gamma correlation test, significant if $\mathrm{p}<0.05$

** Coefficient contingency test, significant if $\mathrm{p}<0.05$ 
Significant correlation between gender and juvenile delinquency can be explained by feministtheoryin which the rate of delinquency in female is lower compared to those in male. The most silent variable that may lead female delinquencytends to be low are history of victimization, stress, and supervision. Research suggests that females had higher risk of being victims than being a delinquent. Feminist researchers found that stress is correlated with negative behavior like delinquency. Females had higher levels of stress then males, but females delinquency tend to lead to self-harm such as mood swing and suicide. That is different from delinquency committed by male which tend to harm other peoples. Research generally finds that females are supervised more closely than males. However, criminologistsproposed that role of gender in the generation of juvenile delinquency is also influenced by the strength of their social relationship, emphasize the interaction between gender and environmental factor. Male adolescences have stronger social relations with their family (family environment) as well as their friends (school environment) (Daigle et al, 2007; Sumara et al, 2017).

Criminologiststated thatthe occurrence of delinquency is increased with age, started from 14 years until next few years. Since subjects in the period of adolescence isalso characterized by emotional condition that are easily challenged, they are vulnerable to experiencing episodes of juvenile delinquency. However, this study showed that age of subjects did not have significant correlation with juvenile delinquency level, but grade of students did. This insignificant correlation between age of subjects and juvenile delinquency level might be due to narrow range of subjects, which were 15-18 years old. The period of adolescence are divided into three stages, i.e early stage adolescence (12-15 years), middle stage (15-18 years old), and late stage (18-21 years) in which all three have certain characteristics based on their self-control ability (Nasution, 2007; Batubara, 2010; Rocque, et.al., 2015).Thismight explain those insignificant correlation.

However, self-control ability in each stage of adolescence is also determined by educational level. Subjects who have highereducationallevel will have better self-control ability. Since selfcontrol ability might also influence juvenile delinquency level, their vulnerability of experiencing juvenile delinquency are lower compared to those with lower educational level (Barseliet.al., 2017). The present study showed that stage of students had significant correlation with juvenile delinquency. A study conducted by Mahmudin (2016) and the theory about association between self-control ability and educational described above support the result of this study.

\section{CONCLUSION}

The stress level was did not significantly correlated to juvenile delinquency level in students of SMK 1 Kuripan. However, other factors, gender and grade of students showed significant correlation with juvenile delinquency. Most of students had mild stress and normal juvenile delinquency level. 


\section{REFERENCES}

Barseli, M., Ifdil , I., \& Nikmarijal, N. (2017). Konsep Stres Akademik Siswa. Jurnal Konseling dan Pendidikan, 5(1), 143-148.

Batubara, J. R. (2010). Adolescent Development (Perkembngan Remaja). Sari Pediatri FKUI. Jakarta, 12(1).

Daigle, L. E., Cullen, F. E. \& Wright, J. P. (2007). Gender Difference in the Predictors of Juvenile Deliquency. Youth Violence and Juvenile Justice, 5(3), pp. 254-286.

Hyland, N. (2018). Juvenile Justice Statistics : Deliquency Cases in Juvenile Court. United States: OOJDP (Office of Juvenile Justice and Deliquency Prevention).

Kementrian Pemuda dan Olahraga. (2009). Penyajian Data Informasi Kementrian Pemuda dan Olahraga Tahun 2009. Jakarta: Biro Perencanaan Sekertariat Kementrian Pemuda dan Olahraga.

Larue, D. E., \& Herman, J. W. (2008). Adolescent Stress Trough The Eyes of High - Risk Teens. Continuing Nursing Education Series, 34(5).

Luluk, S. N. J. \& Veronica, A. (2015). Hubungan antara Tingkat Stres dengan Kenakalan Remaja di SMPN 13 Yogyakarta Tahun 2015. (Skripsi). Universitas Ama Ata.

Mahmudin, T. (2016). Hubungan Tingkat Pendidikan Terhadap Kenakalan Remaja Di Kampung Kebondalem Kelurahan Simolawang Kecamatan Simokerto Kota Surabaya. (Skripsi). Fakultas Pendidikan Agama Islam Universitas Muhammadiyah Surabaya.

Masood, S., \& Ali, S. (2018). Role of Familiy, Neigborhood and Peers in Development of Delinquent Behavior in Adolescents. Peshawar Journal of Psychology and Behavioral Science, 4(2), 171-192.

Nasution, I. K. (2007). Stres Pada Remaja. (Skripsi). Program Studi Psikologi Fakultas Kedokteran Universitas Sumatera Utara.

Papathanasiou, I. V., Tsaras, K., Neroliatsiou, A. \& Roupa, A., 2015. Stress: Concepts, Theorical Models and Nursing Intervention. American Journal of Nursing Science, 4(2 - 1), pp. 45 50.

Pratiwi, I. (2016). Komunikasi Orang Tua - Remaja, Self Esteem dan Tingkat Kenakalan Remaja di Lembaga Pembinaan Khusus Anak (LPKA) Kelas II Bandung. (Skripsi). Departemen Ilmu Keluarga dan Konsumen Fakultas Ekologi Manusia Institut Pertanian Bogor.

Riskinayasari, G. (2015). Kenakalan Remaja Ditinjau Dari Konsep Diri Dan Jenis Kelamin. (Skripsi).Universitas Muhammadiyah Surakarta

Rocque, M., Posick, C., \& Hoyle, J. (2015). Age and Crime. The Ensklopedia of Crime and Punishment, 1, 1-7.

Sumara, D., Humaedi, S., \& Santoso, M. B. (2017). Kenakalan Remaja dan Penanganannya. Jurnal Penelitian \& PPM, 4(2), 129 - 389. 
Wulandari, V. D., 2009. Tingkat Stres Siswa SMA Kelas XII di Yogyakarta dalam Menghadapi Ujiian Nasional. Skripsi Program Psikologi Jurusan Psikologi Fakultas Psikologi. 